\title{
Kekik ve Tarçın Uçucu Yağlarının Yem Bezelyesi Silajlarının Fermantasyon Kalitesi ile In Vitro Metabolik Enerji İçerikleri Üzerine Etkileri Sibel SOYCAN ÖNENÇ ${ }^{*}$, Levent COŞKUNTUNA ${ }^{1}$, Fisun KOÇ ${ }^{1}$, Mehmet Levent ÖZDÜVEN ${ }^{1}$ Tuncay GÜMÜŞ ${ }^{2}$
}

\author{
${ }^{1}$ Namık Kemal Üniversitesi Ziraat Fakültesi Zootekni Bölümü Yemler ve Hayvan Besleme Anabilim Dalı, 59030, Tekirdağ \\ ${ }^{2}$ Namık Kemal Üniversitesi Ziraat Fakültesi Gıda Mühendisliği Bölümü, 59030, Tekirdağ \\ *İletişim (correspondence): e-posta: ssonenc@nku.edu.tr; Tel: +90 (282) 25021 86; Faks: +90 (282) 2509929 \\ Gönderim tarihi (Received): 27 Temmuz 2017; Kabul tarihi (Accepted): 12 Ekim 2017
}

$\ddot{\mathbf{O z}}$

$\mathrm{Bu}$ araştırma kekik (KK) ve tarçın (TRN) uçucu yağlarının, organik asit (OA) alternatifi olarak yem bezelyesi silajlarının fermantasyon kalitesi ve in vitro metabolik enerji (ME) içerikleri üzerine etkilerini belirlemek amacıyla yapılmıştır. Araştırmada kullanılan yem bezelyesi bakla oluşum döneminde hasat edilmiş ( 48 saat soldurma) ve yaklaşık 1.5-2.0 cm boyutunda parçalanmıştır. Parçalanan taze materyale $5 \mathrm{~g} / \mathrm{kg}$ düzeyinde organik asit, $400 \mathrm{mg} / \mathrm{kg}$ kekik uçucu yağ $1,400 \mathrm{mg} / \mathrm{kg}$ tarçın uçucu yağ 1 ve $400+400 \mathrm{mg} / \mathrm{kg}$ kekik +tarçın uçucu yağ $($ KKTRN), kontrol (KON) grubuna ise saf su katılmıştır. Yaklaşık 2 kg örnek plastik torbalara konularak vakumla içindeki hava alınmış ve 2-3 kat streç filmle kaplanmıştır. Silolamadan 120 gün sonra açılmıştır. Araştırmada kullanılan kekik ve tarçın uçucu yağı, yem bezelyesi silajlarının asetik asit (AA) ve Enzimde Çözünen Organik Madde (EÇOM) içeriklerini olumlu yönde etkilemiştir. Ancak, bütün sonuçlar birarada ele alınarak değerlendirildiğinde, silajların sarıldığı kat sayılarının arttırılarak çalışmanın tekrarlanmasının gerekli olduğu sonucuna varılmıştır.

Anahtar kelimeler: Yem bezelyesi, silaj fermantasyonu, uçucu yă̆, metabolik enerji

Effects of Essential Oils of oregano and Cinnamon on Fermentation Quality and In Vitro Metabolic Energy of Field Pea Silages

\begin{abstract}
This study was performed to determine the effect of field pea silages which are the organic acid alternative of Oregano and cinnamon essential oils on fermentation quality and metabolic energy (ME). Whole field pea was harvested at full pod stage and wilted in the laboratory at the $48 \mathrm{~h}$. The chopped pea was mixed and divided into equal portions for application of five treatments: $\mathrm{CON}$; distilled water, denoted as treatment control; treatment $\mathrm{OA}$; organic acid, $5 \mathrm{~g} / \mathrm{kg}$ of fresh forage, treatment ORE; origanum onites L. essential oil at $400 \mathrm{mg}$, treatment CIN; cinnamon essential oil at $400 \mathrm{mg}$, treatment ORECIN; ORE + CIN, a mixture of ORE and CIN applied at an equal rate of $400 \mathrm{mg}$ of fresh forage.The oregano and cinnamon essential oil used in the research affected the acetic acid and Enzymatic solubility of organic matter (ESOM) positively in the 120 day silage of the field pea silages. However, when all the results of the research were evaluated together, it was concluded that it is necessary to repeat the work by increasing the number of layers in which the silages are wrapped.
\end{abstract}

Keywords: Field pea silage, silage fermantation, essential oil, metabolic energy

\section{Giriş}

Baklagiller, ruminantların beslenmesinde kuru ot, silaj ya da otlatılarak kullanılan çok önemli yem kaynaklarıdır (Fernandese et ark., 2013). Akdeniz bölgesi ve özellikle Anadolu da yem bezelyesi (Pisum arvense L.) genellikle ot ya da dane üretimi amaciyla kullanılmaktadır. Ancak, bu bitki bazen tek başına ya da kışlık-yazlık tahıllarla tam daneli kaba yem olarak da yetiştirilmektedir (Ateş, 2012).

Güç silolanan yeşil yemlerden olan yem bezelyesi silolandığında, mutlaka katkı maddesi kullanılması zorunluluğu vardır. Bu grupta yer alan yemlerde şeker içeriği çok düşüktür. Şeker içeriğinin düşük olmas1, fermantasyonun oluşumunu geciktirdiği gibi ortamdaki proteinin bazik özellikteki parçalanma ürünlerinin de silo içerisindeki pH'nın düşmesini engelleyerek, istenmeyen mikroorganizmaların gelişiminin hızlanmasına neden olur (Ergül, 2002). Silajların aerobik bozulması besin madde kaybının yanında hijyenik kaliteyi de olumsuz yönde etkileyerek, patojenik ya da diğer istenmeyen mikroorganizmaların hızla çoğalma riskini artırır (Woolford, 1990). 
Silajın aerobik bozulmasının kontrol edilmesinin amacı, bu sürecin başlamasından sorumlu mikroorganizmaların (çoğunlukla mayalar) büyümesini azaltmak ya da önlemektir (Driehuis ve ark., 1999). Silaj fermantasyonunda kullanılmak üzere, çok sayıda kimyasal ve biyolojik kökenli katkı maddeleri geliştirilmiş durumdadır (Filya, 2000). Silajlardaki maya ve küf gelişimini önlemek, aerobik stabiliteyi artırmak için OA temeline dayalı koruyucu özellikteki katkı maddeleri geniş bir kullanım alanı bulmuştur (Henderson, 1993).

Son yıllarda doğal ürünlere olan ilginin artması, aromatik bitki ve bunlardan elde edilen ürünlerin gıda, hayvan besleme ve tıp alanında kullanımını gündeme getirmiştir. Pek çok bitki ekstraktının mikrobiyal aktiviteyi etkilediği (Covan, 1999) bilinmesine karşın, bunların silaj katkı maddesi olarak kullanımına yönelik sınırlı sayıda (Kung ve ark., 2008; Chaves ve ark., 2012; Soycan-Önenç ve ark., 2015; Turan, 2015) araştırma bulunmaktadır.

$\mathrm{Bu}$ araştırmanın amacı, kekik ve tarçın uçucu yağlarının organik asit alternatifi olarak yem bezelyesi silajına ilavesinin, fermantasyon kalitesi ve in vitro ME içerikleri üzerine etkilerini belirlemektir.

\section{Materyal ve Yöntem}

Araştırmada, silaj materyali olarak Namık Kemal Üniversitesi Ziraat Fakültesi Araştırma ve Uygulama
Merkezi'nde yetiştirilen, Töre çeşidi yem bezelyesi (Pisum arvense L.) kullanılmıştır. Yem bezelyesi Haziran ayının 2. haftasında bakla oluşum döneminde hasat edilmiştir. KM içeriğinin düşük olması nedeniyle 48 saat soldurma yapılmıştır. Katkı maddesi olarak SILOFARM ${ }^{\circledR}$ LIQUID (Farmavet), KK ve TRN uçucu yağları kullanılmıştır. SİLOFARM ${ }^{\circledR}$ LIQUID formik asit temeline dayalı bir koruyucu olup bileşiminde $\% 60$ formik asit, \%20 sodyum formiyat ve \%20 su içermektedir. Kekik ve tarçın uçucu yağları, su destilasyonu yöntemini kullanan ticari bir firmadan temin edilmiş, kimyasal bileşenleri Çizelge 1 'de verilmiştir.

Soldurma işleminin sonunda silaj makinesinde yaklaşık 1.5-2.0 cm boyutlarında parçalanan yem bezelyesine saf su (KON), OA, KK ve TRN uçucu yağları ilave edilmiştir. Organik asit yem bezelyesine $5 \mathrm{~g} / \mathrm{kg}$, kekik uçucu yağ 400 $\mathrm{mg} / \mathrm{kg}$, tarçın uçucu yağı $400 \mathrm{mg} / \mathrm{kg}$ ve kekik+tarçın uçucu yağı $400+400 \mathrm{mg} / \mathrm{kg}$ düzeyinde katılmıştır. Denemede, organik asit, kekik ve tarçın uçucu yağları 1x4 m alanda 6 $\mathrm{kg}$ taze materyale eşit oranda sprey edilmiş ve karıştırılmıştır. Silaj materyali yaklaşı $2 \mathrm{~kg}$ plastik torbalara konularak sıkıştırılmış ve vakumla içindeki hava alınmıştır. Torbalar streç filmle 2-3 kat sarılarak toplam 15 paket silaj oluşturulmuş ve laboratuvar koşullarında (25-30 $\left.{ }^{\circ} \mathrm{C}\right) 120$ gün boyunca fermantasyona bırakılmıştır.

Çizelge 1. Uçucu yağların kimyasal bileşenleri, \%

\begin{tabular}{lrlr}
\hline Kekik & & Tarçın & Miktar \\
\hline Bileşen adı & Miktar & Bileșen adı & 41.50 \\
\hline Carvacrol & 59.03 & Cinnamaldehyde propilene glycol acetal & 35.28 \\
Thymol & 12.04 & Cinnamaldehyde & 2.76 \\
Para Cymen & 6.37 & Propilene glycol & 19.66 \\
Г- Terpinen & 3.86 & Tanımlanamayan & \\
Diğerleri & 18.32 & & 100 \\
Tanımlanamayan & 0.32 & & \\
\hline Toplam & 100 & & \\
\hline
\end{tabular}

Amonyak azotu $\left(\mathrm{NH}_{3}-\mathrm{N}\right)$, suda çözülebilir karbonhidrat (SÇK) ve pH değerleri Anonymous, (1986)'ya göre, laktik asit (LA) ve AA içerikleri Barker ve Summerson (1941) tarafindan geliştirilen spektrofotometrik yönteme göre belirlenmiştir. Başlangıç materyalinin tampon kapasitesi Playne ve McDonals (1996)'a göre belirlenmiştir. Uçucu yağların kimyasal bileşenleri ise gaz kromatografisi-kütle spektrofotometresi (GC/MS, HP 6890 GC/5973 MSD) ile E. Ü. İlaç Geliştirme \& Farmakokinetik AraştırmaUygulama Merkezi (ARGEFAR) laboratuvarında belirlenmiștir.

Weende analiz yöntemine göre silajların yapısındaki ham besin madde içerikleri olan kuru madde (KM), ham protein (HP), ham yağ (HY), ham selüloz (HS), ham kül (HK) ve organik madde (OM) Bulgurlu ve Ergül (1978)'e göre belirlenmiştir. Van Soest ve ark. (1991)'na göre yemlerin hücre duvarı bileşenlerini oluşturan nötr deterjanda çözünmeyen lif (NDF), asit deterjanda çözünmeyen lif (ADF) ve asit deterjanda çözünmeyen lignin (ADL) içerikleri belirlenmiştir. Hemiselüloz ve selüloz hesap yolu ile bulunmuştur. Selülaz yöntemiyle (Naumann ve Bassler, 1993) örneklerin EÇOM miktarları bulunmuştur. Kimyasal analizler sonunda elde edilen sonuçlara göre aşağıdaki eşitlikler kullanılarak in vitro ME içerikleri hesaplanmıştır. 
$\mathrm{ME}_{\mathrm{EÇOM}} * * \mathrm{MJ} / \mathrm{kg} \quad \mathrm{KM}=0.54+0.001987 \quad \mathrm{HP}+0.01537$ EÇOM+0.000706 HY x HY-0.00001262 EÇOM x HK0.00003517 EÇOM x HP (Jeroch ve ark, 1999)

HP, HY, HK, EÇOM değerleri g/kg KM içinde.

$\mathrm{ME}_{\mathrm{HBM}}, \mathrm{ME}, \mathrm{kcal} / \mathrm{kg} \mathrm{OM}=3260+\left(0.455 \times \mathrm{HP}^{*}+3.517\right.$

x HY*)-4.037 x HS* (TSE, 1991)

*Değerler g/kg OM'dir.

$\mathrm{ME}_{\mathrm{NDF}}, \quad \mathrm{kcal} / \mathrm{kg} \quad \mathrm{KM}=3381.9-19.98 \quad \mathrm{x} \quad \mathrm{NDF}^{*}$

(Kirchgessner ve ark., 1977)

$\mathrm{ME}_{\mathrm{ADF}}, \quad * * \mathrm{MJ} / \mathrm{kg} \quad \mathrm{KM}=14.70-0.150 \quad \mathrm{x} \quad \mathrm{ADF}^{*}$

(Kirchgessner ve Kellner, 1981)

$\mathrm{ME}_{\mathrm{ADL}}, \quad \mathrm{kcal} / \mathrm{kg} \quad \mathrm{KM}=2764.4-102.73 \quad \mathrm{x} \quad \mathrm{ADL}^{*}$

(Kirchgessner ve ark., 1977)

* NDF, ADF ve ADL değerleri \% olarak alınmıştır ** ME içerikleri kilokaloriye çevrilmiştir.

Araştırma sonunda elde edilen veriler SPSS v.16 istatistik paket programının (SPSS Inc., 2007) GLM prosedüründe değerlendirilmiştir. Grup ortalamaları arasındaki farklılıkların karşılaştırılmasında Duncan testi kullanılmıştır (Efe ve ark., 2000).

\section{Araștırma Bulguları}

Silajlara OA, KK, TRN ve KKTRN katılması HP oranını KON'a göre düşürürken $(\mathrm{P}<0.01) \mathrm{HS}$, NDF ve $\mathrm{ADF}$ içeriklerini artırmıştır $(\mathrm{P}<0.01)$. Yem bezelyesine katkı maddesi ilavesi KM içeriğini KON' a göre önemli
$(\mathrm{P}<0.01)$ düzeyde artırmıştır (Çizelge 2). $\mathrm{Bu}$ artış en yüksek TRN silajında \% 25.68 belirlenirken bunu OA (\%25.53) silajı takip etmiştir. KON'da ise KM içeriği $\% 22.79$ olarak belirlenmiştir (Çizelge 3). Bu dönemde silajların pH değerleri 5.18-5.70 arasında bulunmuştur. Silajlara OA, KK ve KKTRN ilavesi kuru madde kaybını (KMK) önlemede etkili olmamıştır. En düşük KMK $\% 1.72$ oranında KON grubunda, en yüksek ise \%3.43 ile KKTRN grubunda gerçekleşmiştir $(\mathrm{P}<0.01)$. Bunun yanı sıra tüm silajlarda SÇK içeriklerinin önemli düzeyde farklı olduğu bulunmuştur $(\mathrm{P}<0.01)$.

KK, TRN ve KKTRN fermantasyonun son ürünleri olan LA ve AA konsantrasyonlarını önemli düzeyde düşürürken $(\mathrm{P}<0.01), \mathrm{NH}_{3}-\mathrm{N}$ düzeyini artırmıştır $(\mathrm{P}<0.01)$.

Yem bezelyesine Kekik, Tarçın ve Kekik-tarçın katılması EÇOM miktarını artırmıştır (Çizelge 4). EÇOM miktarından yararlanılarak hesaplanan ME içerikleri OA, KK, TRN ve KKTRN silajlarında KON göre önemli düzeyde $(\mathrm{P}<0.01)$ yüksek bulunmuştur. Çizelge 4'den de görüldüğü gibi, farklı regresyon eşitlikleri kullanılarak hesaplanan ME içeriklerinin $\mathrm{ME}_{\mathrm{ADL}}$ 'de dışında KON'da en yüksek olduğu belirlenirken $\mathrm{ME}_{\mathrm{ADL}}$ 'de en yüksek $\mathrm{KK}$ grubunda belirlenmiştir $(\mathrm{P}<0.01)$.

\begin{tabular}{|c|c|c|c|c|c|c|c|c|c|c|c|}
\hline Grup & $\mathrm{OM}$ & HP & HY & HS & NÖM & HK & NDF & $\mathrm{ADF}$ & $\mathrm{ADL}$ & Hemiselüloz & Selüloz \\
\hline BM & 92.64 & 23.37 & 1.98 & 22.20 & 45.09 & 7.36 & 39.95 & 25.08 & 8.98 & 14.87 & 16.10 \\
\hline KON & $92.04 \pm 0.01^{\mathrm{A}}$ & $22.60 \pm 0.02^{\mathrm{a}}$ & $2.71 \pm 0.06^{b}$ & $23.66 \pm 0.09^{e}$ & $43.07 \pm 0.04^{\mathrm{c}}$ & $7.96 \pm 0.01^{\mathrm{B}}$ & $37.67 \pm 0.08^{c}$ & $26.36 \pm 0.06^{d}$ & $8.94 \pm 0.13^{c}$ & $11.31 \pm 0.14^{d}$ & $17.42 \pm 0.08^{c}$ \\
\hline $\mathrm{OA}$ & $91.83 \pm 0.08^{\mathrm{B}}$ & $21.46 \pm 0.10^{c}$ & $2.45 \pm 0.02^{\mathrm{d}}$ & $24.66 \pm 0.08^{c}$ & $43.26 \pm 0.04^{b}$ & $8.17 \pm 0.08^{A}$ & $40.86 \pm 0.38^{b}$ & $27.99 \pm 0.02^{b}$ & $10.09 \pm 0.21^{\mathrm{b}}$ & $12.87 \pm 0.38^{b}$ & $17.90 \pm 0.23^{\mathrm{c}}$ \\
\hline KK & $91.82 \pm 0.02^{\mathrm{B}}$ & $21.91 \pm 0.04^{b}$ & $2.58 \pm 0.22^{c}$ & $24.15 \pm 0.01^{\mathrm{d}}$ & $43.17 \pm 0.01^{\mathrm{bc}}$ & $8.18 \pm 0.02^{\mathrm{A}}$ & $40.74 \pm 0.03^{b}$ & $29.28 \pm 0.07^{\mathrm{a}}$ & $6.99 \pm 0.21^{\mathrm{d}}$ & $11.46 \pm 0.09^{\mathrm{d}}$ & $22.29 \pm 0.15^{\mathrm{a}}$ \\
\hline TRN & $92.05 \pm 0.02^{\mathrm{A}}$ & $21.85 \pm 0.03^{b}$ & $2.85 \pm 0.01^{\mathrm{a}}$ & $25.15 \pm 0.06^{\mathrm{b}}$ & $42.21 \pm 0.05^{\mathrm{d}}$ & $7.95 \pm 0.02^{\mathrm{B}}$ & $41.51 \pm 0.07^{\mathrm{a}}$ & $27.16 \pm 0.24^{c}$ & $11.89 \pm 0.17^{\mathrm{a}}$ & $14.34 \pm 0.16^{\mathrm{a}}$ & $15.27 \pm 0.41^{\mathrm{d}}$ \\
\hline KKTRN & $92.11 \pm 0.10^{\mathrm{A}}$ & $20.59 \pm 0.02^{\mathrm{d}}$ & $2.32 \pm 0.01^{\mathrm{e}}$ & $25.59 \pm 0.01^{\mathrm{a}}$ & $43.61 \pm 0.09^{\mathrm{a}}$ & $7.89 \pm 0.10^{\mathrm{B}}$ & $41.00 \pm 0.10^{\mathrm{ab}}$ & $28.86 \pm 0.19^{\mathrm{a}}$ & $9.33 \pm 0.09^{c}$ & $12.14 \pm 0.14^{\mathrm{c}}$ & $19.52 \pm 0.10^{b}$ \\
\hline $\mathrm{P}$ & 0.05 & 0.01 & 0.01 & 0.01 & 0.01 & 0.05 & 0.01 & 0.01 & 0.01 & 0.01 & 0.01 \\
\hline
\end{tabular}

BM:Baslangıc materyali, OA:Organik acid,KK:Kekik, TRN:Tarcın, KKTRN:Kekik+tarçn OM: Organik madde, HP:Ham protein, HY:Ham yağ, HS:Ham selüloz, NÖM:N'siz öz madde, HK:Ham kül, NDF:Nötral cözücülerde cözünmeyen lif, ADF:Asit cözücülerde çözünmeyen lif, ADL:Asit çözücülerde çözünmeyen lif. ab,c: Aynı sütunda bulunan farklı harfler önemlidi $(\mathrm{P}<0.01), \mathrm{A}, \mathrm{B}, \mathrm{C}:$ Ayn1 sütunda bulunan farklı harfler önemlidir $(\mathrm{P}<0.05)$.

Çizelge 3. Bașlangıç materyali ve silajların kimyasal analiz sonuçlanı

\begin{tabular}{|c|c|c|c|c|c|c|c|}
\hline Grup & $\mathrm{KM}(\%)$ & $\mathrm{pH}$ & $\mathrm{SCK}(\mathrm{g} / \mathrm{kg} \mathrm{DM})$ & LA $(\mathrm{g} / \mathrm{kg} \mathrm{KM})$ & $\mathrm{AA}(\mathrm{g} / \mathrm{kg} \mathrm{KM})$ & $\mathrm{NH}_{3}-\mathrm{N}(\mathrm{g} / \mathrm{kg} \mathrm{TN})$ & KMK (\%) \\
\hline BM & 31.17 & 6.06 & 38.02 & - & - & - & - \\
\hline KON & $22.79 \pm 0.16^{\mathrm{d}}$ & $5.18 \pm 0.01^{\mathrm{B}}$ & $6.94 \pm 0.00^{\mathrm{d}}$ & $45.26 \pm 1.13^{\mathrm{a}}$ & $26.96 \pm 0.20^{\mathrm{a}}$ & $99.08 \pm 0.28^{\mathrm{d}}$ & $1.72 \pm 0.20^{b}$ \\
\hline $\mathrm{OA}$ & $25.53 \pm 0.13^{\mathrm{ab}}$ & $5.70 \pm 0.14^{\mathrm{A}}$ & $6.43 \pm 0.06^{\mathrm{e}}$ & $32.93 \pm 1.48^{b}$ & $24.11 \pm 0.19^{b}$ & $89.16 \pm 0.30^{\mathrm{e}}$ & $3.40 \pm 0.23^{\mathrm{a}}$ \\
\hline $\mathrm{KK}$ & $25.08 \pm 0.23^{\text {bc }}$ & $5.50 \pm 0.01^{\mathrm{A}}$ & $7.45 \pm 0.06^{c}$ & $30.52 \pm 2.18^{b}$ & $19.63 \pm 0.41^{\mathrm{d}}$ & $131.21 \pm 0.21^{\mathrm{c}}$ & $3.41 \pm 0.24^{\mathrm{a}}$ \\
\hline TRN & $25.68 \pm 0.06^{\mathrm{a}}$ & $5.49 \pm 0.06^{\mathrm{A}}$ & $9.28 \pm 0.06^{\mathrm{a}}$ & $23.99 \pm 0.97^{\mathrm{c}}$ & $22.95 \pm 0.10^{c}$ & $136.85 \pm 0.10^{\mathrm{b}}$ & $1.93 \pm 0.07^{\mathrm{b}}$ \\
\hline KKTRN & $25.02 \pm 0.10^{c}$ & $5.51 \pm 0.03^{\mathrm{A}}$ & $8.51 \pm 0.30^{\mathrm{b}}$ & $28.09 \pm 1.31^{\mathrm{bc}}$ & $19.24 \pm 0.22^{\mathrm{d}}$ & $144.13 \pm 0.23^{\mathrm{a}}$ & $3.43 \pm 0.01^{\mathrm{a}}$ \\
\hline $\mathrm{P}$ & 0.01 & 0.05 & 0.01 & 0.01 & 0.01 & 0.01 & 0.01 \\
\hline
\end{tabular}

BM:Baslangıc materyali, OA:Organik acid.KK:Kekik. TRN:Tarcın, KKTRN:Kekik+tarcın. KM:Kuru madde, SCK:Suda cözülebilir karbonhidrat, LA:Laktik asit, AA:Asetik asit, NH $\mathrm{N}$ :Amonyak azotu.KMK: Kuru madde kayb1,, a.b.c:Aynı sütunda bulunan farklı harfler önemlidir $(\mathrm{P}<0.01)$, A B, C: Ayn1 sütunda bulunan farklı harfler önemlidir $(\mathrm{P}<0.05)$.

Çizelge 4. Başlangıç materyali ve silajların EÇOM ve ME içerikleri, Kcal/kg KM

\begin{tabular}{lcccccc}
\hline Grup & EÇOM $(\%$ DM) & MEEÇOM & MEHBM & MENDF & MEADF & MEADL \\
\hline BM & $64.36 \pm 0.23^{\mathrm{B}}$ & $1348 \pm 6.36^{\mathbf{c}}$ & $2244 \pm 5.49^{\mathbf{a}}$ & $2629 \pm 1.69^{\mathbf{a}}$ & $2569 \pm 2.04^{\mathbf{a}}$ & $1846 \pm 12.89^{\mathbf{b}}$ \\
KON & $64.31 \pm 0.17^{\mathrm{B}}$ & $1376 \pm 5.46^{\mathbf{b}}$ & $2182 \pm 6.25^{\mathbf{c}}$ & $2566 \pm 7.56^{\mathbf{b}}$ & $2510 \pm 0.75^{\mathbf{c}}$ & $1727 \pm 21.64^{\mathbf{c}}$ \\
OA & $65.26 \pm 0.16^{\mathrm{A}}$ & $1380 \pm 5.24^{\mathbf{b}}$ & $2209 \pm 0.40^{\mathbf{b}}$ & $2568 \pm 0.52^{\mathbf{b}}$ & $2464 \pm 2.38^{\mathbf{d}}$ & $2046 \pm 21.11^{\mathbf{a}}$ \\
KK & $64.41 \pm 0.14^{\mathrm{AB}}$ & $1398 \pm 2.31^{\mathbf{b}}$ & $2185 \pm 2.87^{\mathbf{c}}$ & $2553 \pm 1.49^{\mathbf{c}}$ & $2540 \pm 8.43^{\mathbf{b}}$ & $1543 \pm 17.53^{\mathbf{d}}$ \\
TRN & $65.64 \pm 0.86^{\mathrm{A}}$ & $1436 \pm 15.93^{\mathbf{a}}$ & $2145 \pm 3.20^{\mathbf{d}}$ & $2563 \pm 1.90^{\mathbf{b c}}$ & $2479 \pm 6.70^{\mathbf{d}}$ & $1805 \pm 9.69^{\mathbf{b}}$ \\
\hline P & 0.05 & 0.01 & 0.01 & 0.01 & 0.01 & 0.01 \\
\hline
\end{tabular}

BM:Başlangıç materyali, OA:Organik acid,KK:Kekik, TRN:Tarçın, KKTRN:Kekik+tarçın, abc: aynı sütunda bulunan farklı harfler önemlidir $(\mathrm{P}<0.01)$. A,B, C: Aynı sütunda bulunan farklı harfler önemlidir $(\mathrm{P}<0.05)$. 


\section{Tartışma}

Formik ve propiyonik asit fermantasyon inhibitörü olarak silaj yapımında en çok kullanılan silaj katkı maddeleridir. Bunlar silo içerisinde ya aerobik ya da anaerobik dönemde mikroorganizmaların gelişmesini inhibe ederek etki gösterirler (Kurtoğlu, 2011). Farklı dönemlerde hasad edilen yem bezelyesine $2 / 1$ oranında formik ve propiyonik asit karışımı ilave eden Rondahl ve ark., (2011), 102 günlük silolama sonunda açılan silajlarda pH'nın 3.8-4.7 arasında değiştiğini bildirmektedir. Bizim bulgularımız (5.18-5.70) Rondahl ve ark., (2011)'nın bildirdiği değerlerin üzerindedir. Baklagiller gibi SÇK bakımından fakir olan bitkilerde, süt asidi oluşumu için koşullar elverişli olmadığı gibi proteince zengin ve parçalanma ürünleri bazik reaksiyonlu olduğundan, siloda $\mathrm{pH}$ 'nın düş̧erek ortamın asidik olması zorlaşır.

Rondahl ve ark., (2011) yem bezelyesi silajlarının KM içeriğinin \%14.5-18.5 arasında değiştiğini belirlerken, araştırmada \%20.59-22.60 arasında belirlenmiştir. Bulgularımızın Rondahl ve ark., (2011)'dan yüksek olması, vejetasyon dönemi farkından ya da yapılan soldurmadan kaynaklanmış olabilir. KON ve TRN silajlarının KM kayıplarının benzer bulunması, diğer muamelelerde ise yüksek oluşu paketlemeden kaynaklanmış olabilir. Rondahl ve ark., (2011) OA katılan yem bezelyesi silajlarında SÇK içeriklerinin 0.7$104.0 \mathrm{~g} / \mathrm{kg} \quad \mathrm{KM}$ arasında değişim gösterdiğini bildirmişlerdir. Araştırmada belirlenen SÇK içerikleri Rondahl ve ark., (2011)'nın bildirişleriyle uyumludur.

Rondahl ve ark. (2011)'nın çalışmasında, yem bezelyesine katılan OA miktarındaki artmaya paralel olarak AA ve $\mathrm{NH}_{3}-\mathrm{N}$ düzeyinde düşme ortaya çıkmıştır. Formik asit kaba yemlerdeki azotlu bileşiklerin proteolizisi ve deaminasyonunda azalmayla etki gösterir (Mc Donald ve ark., 1991). Timol ve karvakrol gibi fenolik yapilı bileşiklerin fenolik yapılarında bulunan hidroksil grubunun varllğı nedeniyle diğer ikincil bitki bileşenlerine göre antimikrobiyal etkisinin daha yüksek olduğu bildirilmektedir (Helander ve ark., 1998; Ultee ve ark., 2002). Ancak, araştırmada kullanılan kekik uçucu yağında temel bileşen olarak \%59.03 karvakrol ve \%12.04 oranında timol bulunmasına karşın, silolamanın 120. gününde açılan silajlarda $\mathrm{pH}$ ve $\mathrm{NH}_{3}-\mathrm{N}$ düzeyinin $\mathrm{KON}$ 'a göre yüksek oluşu söz konusu bileşenlerin depolamaya bağlı olarak antimikrobiyal aktivitesinde düşme olmasından kaynaklanmış olabilir. Bununla birlikte, paketleme sırasında streç film katının yetersizliği (2-3) ve son olarak bir kat da bant geçilmemiş olması, uçucu yağların silajdan uçmasına neden olmuş olabilir. KON grubunun KMK'sının muamelelerden düşük olması da bu olasıllı̆ı güçlendiriyor.

Silajlarda sarılan streç kat sayısını artırmanın örtü materyalinin gaz geçirmezliğini artırarak, daha etkin bir silaj fermantasyonun oluşmasına yardımcı olduğu, üretilen silajın içerdiği maya ve küf sayılarının da düşük olduğu bilinmektedir. Yonca balyaları ile yapılan bir çalışmada, 2 kat streçlenmiş film ile sarmanın Amerika koşullarında 5 aylık silolama süresince yetersiz, 4 ya da 6 kat sarmanın ise fermantasyon özelliklerini benzer şekilde etkilemiştir (Hancock ve Collins, 2006). Başka bir çalışmada, 286, 321 ve $434 \mathrm{~g} / \mathrm{kg}$ KM'li çayır silajlarını 2 kat sarma ile KM sindirilebilirliğinin düşerek silaj kalitesinin bozulduğu, 4 ve 6 kat sarılanlarda fermantasyon özelliklerinin birbirine benzer olduğu, 6 kat sarılanların ise bozulmuş silaj yüzeylerinin daha az olduğu bildirilmiş̧tir (Keleş ve ark., 2009).

Rondahl ve ark., (2011) formik ve propiyonik asit katılarak 103 günlük silolanan bezelye silajlarında HP içeriğinin \%24.6-27.3, HK \%5.4-13.6 arasında değiştiğini bildirmektedir. Bizim çalı̧̧mamızda silolamanın 120 . gününde açılan silajlarda belirlenen HP miktarları Rondahl ve ark., (2011)'nın altında, HK miktarları ise benzer bulunmuştur.

Kolay çözülebilir karbonhidratça zengin yemlerde formik asidin kullanımı ile laktat fermantasyonu şekillenmektedir. Asetik asit üretiminin azalması sonucu istenilen düzeyde bir fermantasyon gerçekleşmektedir. Yüksek düzeyde formik asidin kullanılmasıyla karbonhidrat içeriği yüksek silajlarda, polisakkaritlerin hidrolizi sonucu şeker artışı olmaktadır (Mc Donald ve ark., 1991). Oysa bu araştırmada muamele gruplarının NDF, ADF ve SÇK içerikleri KON'a göre yüksek bulunurken, LA ve AA içerikleri düşük bulunmuştur.

Filya ve ark. (2004) formik asit temeline dayalı koruyucuların (FAT) mısır silajlarının $\mathrm{KM}$ ve $\mathrm{OM}$ parçalanabilirliklerini artırdığını, araştırıcılar bu durumu FAT'in antimikrobiyal etkisiyle silaj mikroorganizmalarının (maya, küf, enterobacter ve clostridia) gelişimini engellemesinden kaynaklanmış olmasıyla açıklamıştır. Başka bir çalışmada formik asitin domuz ayrığı ve yonca silajlarının KM sindirilebilirliğini artırdığı bildirilmiştir (Nadeau ve ark., 2000). SoycanÖnenç ve ark. (2015) kekik ve tarçın uçucu yağlarının 60. günlük depolamada yem bezelyesinin EÇOM içeriklerini etkilemediğini, bu araştırmada ise TRN ve KKTRN'ın EÇOM'u arttırdığı bulunmuştur. Turan (2015) kimyon uçucu yağının formik asite benzer etki gösterdiğini ve EÇOM'un kontrol grubuna göre arttı̆ğını bildirmiştir. $\mathrm{Bu}$ 
araştırmada, EÇOM miktarından yararlanılarak hesaplanan ME içerikleri OA, KK, TRN ve KKTRN silajlarında KON'a göre, Turan (2015)'in çalışmasıyla benzer şekilde yüksek bulunmuştur.

Farklı regresyon eşitlikleri kullanılarak hesaplanan ME içeriklerinin $\mathrm{ME}_{\mathrm{ADL}}$ 'nin dışında KON'da yüksek oluşu, Turan (2015)'nın bulgularından farklıdır. Bunun nedeni kullanılan uçucu yağların, ME eşitliklerinde kullanılan ham besin madde içeriklerini özellikle de NDF, ADF ve ADL gibi hücre çeperi fraksiyonlarına olan etkisiyle açıklanabilir.

Silajlarda kullanılan katkı maddelerinin etkisi genellikle silajın $\mathrm{pH}, \mathrm{NH}_{3}-\mathrm{N}, \mathrm{LA}, \mathrm{AA}$ ve bütürik asit içeriği gibi fermantasyon kriterlerine bakılarak belirlenir (Spoelstra, 1991). Söz konusu kriterlere bakılarak kullanılan katk1 maddesi fermantasyon uyarıcı, fermantasyon ve aerobik bozulmayı engelleyici, substrat yani besin maddesi ya da absorbanlar grubunda değerlendirilir (Mc Donald ve ark., 1991). Bu araştırmada kullanılan kekik ve tarçın uçucu yağının silaj katkıları arasında hangi grup içerisinde değerlendirilebileceğini söylemek henüz mümkün değildir. Bilindiği gibi formik asit fermantasyonu engelleyici etki gösterirken propiyonik asit aerobik bozulmayı engelleyici etki göstermektedir (McDonald ve ark., 1991). Bir fenol olan timol hücre membranlarındaki membran proteinlerini parçalar, $\mathrm{H}^{+}$ve $\mathrm{K}^{+}$gibi katyonların geçirgenliğini değiştirerek hücrenin temel görevlerinin aksamasına neden olur. Hücre içi öğelerin hücre dışına çıkmasını sağlar, su dengesinin bozulması sonucu hücre ölür. Bu etki yolu nedeniyle fenollere direnç gelişemez (Ultee ve ark., 2002). Uçucu yağların etki mekanizmaları dikkate alındığında, fermantasyonu ya da aerobik bozulmayı engelleyici gruplardan birinde yer alacaktır.

\section{Sonuç}

Araştırmada kullanılan kekik ve tarçın uçucu yağı, yem bezelyesi silajlarının 120 gün silolanmasında AA ve EÇOM içeriklerini olumlu yönde etkilemiştir. Ancak, araştırmanın bütün sonuçları birarada değerlendirildiğinde, silajların sarıldığı kat sayılarının arttırılarak çalışmanın tekrarlanmasının gerekli olduğu sonucuna varılmıştır.

\section{Teșekkür}

$\mathrm{Bu}$ araştırma Namık Kemal Üniversitesi Bilimsel Projeleri NKUBAP.00.24.AR.11.04. no lu projeyle desteklenmiştir.

\section{Kaynaklar}

Anonymous, 1986. The Analysis of Agricultural Material, Reference Book: 427- 428 p, London.

Ateş E. 2012. The mineral, amino acid and fiber contents and forage yield of field pea (Pisum Arvense L.), fiddleneck (Phacelia Tanacetifolia Benth.) and their mixtures under dry land conditions in the Western Turkey. Romanian Agricultural Research 29:237244.

Barker SB, Summerson WH. 1941. The colorimetric determination of lactic acid in biological material. Journal of Biological Chemistry 138:535-554.

Bulgurlu Ş, Ergül M. 1978. Yemlerin fiziksel kimyasal ve biyolojik analiz metotları. Ege Üniversitesi Ziraat Fakültesi Baskı Yayın No: 127, İzmir.

Chaves AV, Baah J, Wang Y, McAllister TA, Benchaar C. 2012. Effects of cinnamon leaf, oregano and sweet orange essential oils on fermentation and aerobic stability of barley silage. Journal of Science Food Agriculture 92:906-915.

Covan MM. 1999. Plant products as antimicrobial agents. Clinal Microbiology Reviews 12:564-582.

Driehuis F, Oude Elferink SJWH, Spoelstra S F.1999. Anaerobic lactic acid degradation during ensilage of whole crop maize inoculated with Lactobacillus buchneri inhibits yeast growth and improves aerobic stability. Journal of Applied Microbiology 87:583594.

Efe E, Bek Y, Şahin M. 2000. SPSS'te çözümleri ile istatistik yöntemler II. Kahramanmaraş Sütçü İmam Üniversitesi, Yayın No:73, Ders Kitabı Yayın No:9.

Ergül M. 2002. Yemler bilgisi. Ege Üniversitesi Ziraat Fakültesi Baskı Yayın No: 487, İzmir.

Fernandes GM, Possentib RA, Mattosc WT, Schammassd EA, Juniore EF. 2013. In situ degradability and selected ruminal constituents of sheep fed with peanut forage hay. Archives of Animal Nutrition 67(5):393-405.

Filya İ. 2000. Silaj kalitesinin artırılmasında yeni gelişmeler. Internationall Animal Nutrition Congress 2000. S243-250.

Filya İ, Sucu E, Hanoğlu H. 2004. A research on the quality characteristics and nutritive value of small plastic bale maize silages ensiled with biological silage additives and their use in lamb fattening. Ankara Üniversitesi Tarım Bilimleri Dergisi 10(2):158-162. 
Jeroch H, Drochner W, Simon O. 1999. Nutrition on farm livestock. Verlag Eugen Ulmer Stuttgart. 525 p.

Hancock DW, Collins M. 2006. Forage preservation method influences alfalfa nutritive value and feeding characteristics. Crop Science 46: 688-694.

Helander I M, Alakomi H-L, Latva-Kala K, MattilaSandholm T, Pol I, Smid EJ, Gorris LGM, Von Wright A. 1998 Characterization of the action of selected essential oil components on gram-negative bacteria. Journal of Agricultural and Food Chemistry, 46:3590-3595.

Henderson N. 1993. Silage additives. Animal Feed Science and Technology 45: 35-56.

Kirchgessner M, Kellner RJ, Roth FX, Ranfft K. 1977. Zur schätzung des futterwertes mittels rohfaser und der zellwandfraktionen der detergentien-analyse. Landwirtschaft Forschung. 30:245-250.

Kirchgessner M, Kellner RJ. 1981. Schätzung des energiegehaltes futterwerttest von grün-und rauhfutter durch die cellulase methode. Landwirtschaft Forschung 34 (4):276-281.

Keles G, O’Kiely P, Lenehan JJ, Forristal PD. 2009. Conservation characteristics of baled grass silages differing in duration of wilting, bale density and number of layers of plastic stretch-film. Irish Journal of Agricultural Food Research 48: 21-34.

Kung JL, Williams P, Schmidt RJ, Hu W. 2008. A blend of essential plant oils used as an additive to alter silage fermentation or used as a feed additive for lactating dairy cows. Journal of Dairy Science 91:4793-4800.

Kurtoğlu V. 2011. Silaj ve silaj katkıları. Aybil Yayınevi, Konya.

McDonald P, Henderson AR, Heron SJE. 1991. The biochemistry of silage. sekond edition p.340, Chalcombe publication, Marlow, England.

Nadeau EMG, Buxton DR, Russell JR, Allison MJ, Young JW. 2000. Enzyme, bacterial inoculant, and formic acid effects on silage composition of orchardgrass and alfalfa. Journal of Dairy Sci 83:1487-1502.
Naumann C, Bassler R. 1993. Methoden Buch, B. III. Die chemische untersuchung von futtermitteln. VDLUFA- Verlag, Darmstadt.

Playne MJ, McDonald P. 1966. The buffering constituent of herbage and silage. Journal of Science Food Agriculture 17: 264-268.

Rondahl T, Bertilsson J, Martinsson K. 2011. Effects of maturity stage, wilting and acid treatment on crude protein fractions and chemical composition of whole crop pea silages (Pisum sativum L.). Animal Feed Science and Technology 163:11-19.

Soycan-Önenç S, Koç F, Coşkuntuna L, Özdüven ML, Gümüş T. 2015. The effect of oregano and cinnamon essential oils on fermentation quality and aerobic stability of field pea silages. Asian-Austrasian Journal of Animal Science 28(9):1281-1287.

Spoelstra SF. 1991. Chemical and biological additives in forage conservation. Eds: Pahlow G. and Honig H. In Forage Conservation Towards 2000. Institut Grassland Forage Research, Braunschweigh, Germany. pp. 48-70.

SPSS Inc., 2007. SPSS for Windows, Version 16.0. Chicago, SPSS Inc.

TSE 1991. Hayvan yemleri- metabolik (çevrilebilir) enerji tayini (kimyasal - metod). TS 9610, Aralık 1991, Ankara.

Turan A. 2015. Kimyon uçucu yağının yonca silajının fermantasyon kalitesi ve aerobik stabilitesi üzerine etkisi. Namık Kemal Üniversitesi Fen Bilimleri Enstitüsü, Tekirdağ.

Ultee A, Bennik HJ, Moezelaar R. 2002. The phenolic hydroxyl group of carvacrol is essential for action against the food-borne pathogen. Bacillus cereus. Applied Environmental Microbiology 3: 1561-1568.

Van Soest PJ, Robertson JB, Lewis BA. 1991. Method for dietary fiber, neutral detergent fiber and nonstarch polysaccharides in relation to animal nutrition. Journal of Dairy Science 74: 3583-3597.

Woolford MK. 1990. A review, the detrimental effects of air on silage. Journal of Applied Bacteriology 68:101106. 